\title{
A Study Transactional Relationships and Longitudinal Effects Between Parents-Children Language/Physical Play Activity and Children's Vocabulary Development
}

\author{
Ji-Yeong Joo ${ }^{1}$, Sae-Young $\mathrm{Han}^{2}$ \\ Lecturer, Department of Social Service Counseling, Sunchon National University, Sunchon, Korea ${ }^{1}$ \\ Professor, Department of Child Development, Ewha Womans University, Seoul, Korea² \\ 부모-자녀의 언어/신체놀이 활동 참여와 자녀 어휘발달의 \\ 상호교류관계 및 종단적 효과: 영국의 유아기와 아동기를 대상으로 \\ 주지영 ${ }^{1}$ 한세영 ${ }^{2}$ \\ 순천대학교 사회서비스상담학과 강사 ${ }^{1}$, 이화여자대학교 아동학과 교수 ${ }^{2}$
}

Objectives: This study explored the longitudinal effectiveness of parents-children language/physical play activity on later children's vocabulary development.

Methods: Three waves of panel data from the Millennium Cohort Study in the United Kingdom were analyzed in this study. A total of 9,420 three-year-old (T1), five-year-old (T2) and eleven-year-old children (T3) and their parents.

Results: First, Parents-children language/physical play activity and children vocabulary development showed stability. Second, $\mathrm{T} 1$ and $\mathrm{T} 2$ parent-children language activity had effects on T2 and T3 children vocabulary development. Considering child effects, parents-children language activity was influenced by children vocabulary development. Third, $\mathrm{T} 1$ and $\mathrm{T} 2$ mother-children physical play activity had effects on $\mathrm{T} 2$ and $\mathrm{T} 3$ children vocabulary development. The father-children physical play activity (T2) had only effect on children vocabulary development (T3). For child effects, father-children physical activity was influenced by children vocabulary development only.

Conclusion: This study identified the child effects as well as parent effects supporting the transactional model. Findings of this study also stressed the differences between the effects of fathers and mother involvement. Furthermore, they can be used as a source in developing policies for children with delayed language development and their parents.

Keywords: parents-children language/physical play activity, children's vocabulary development, longitudinal effect

\section{Introduction}

언어는 우리 삶 속에 복잡하게 연결되어 있으며 사람들의 생 각, 가치, 태도 등을 전달하는 중요한 수단이다. 무엇보다 언

Corresponding Author: Sae-Young Han, Professor, Department of Child Development, Ewha Womans University, 52, Ewhayeodae-gil, Seodaemungu, Seoul, Korea

E-mail: evenhow@ewha.ac.kr
어 영역 중 어휘 영역은 읽기, 말하기, 쓰기, 듣기 등의 모든 언 어 사용 능력의 기본이기에 풍부한 어휘를 습득하는 것은 유 창한 언어 능력의 핵심적 요소라 할 수 있다(K. S. Lee, Kim, \& Kim, 2011). 어휘력은 영아기부터 시작하여 유아기를 거쳐 급

(c)The Korean Association of Child Studies

This is an Open Access article distributed under the terms of the Creative Commons Attribution Non-Commercial License (http:// creativecommons.org/licenses/by-nc/4.0) which permits unrestricted noncommercial use, distribution, and reproduction in any medium, provided the original work is properly cited. 
속하게 발달하기 시작한다. 언어학자들에 따르면 유아기는 어 휘 능력이 급속도로 발달하는 어휘 폭발기로(Glazer \& Burke, 1994), 특히, 유아기 어휘는 세상에 존재하는 여러 가지 상황 들을 개념화할 수 있는 인지적 수단이 되며, 자신의 정서를 표 현하거나 통제하는 연결고리가 되어(Piaget, trans., 1954), 이후 발달의 중요한 기초가 된다. 더욱이 유아기의 어휘발달은 이 후의 발단단계까지 밀접하게 연결되어 있어 유아기에 어휘력 이 부족할 경우 아동 후기 언어로 표현되는 담화, 유추, 추론 능력 등에 언어적 결함이 발생할 수 있다(Girolametto, Wiigs, Smyth, Weitzman, \& Pearce, 2001).

이러한 어휘능력 중 표현 어휘는 아동의 말과 글을 통해 어 휘발달을 평가함으로써 아동의 언어능력이 얼마나 발달했는 지 그 예후에 대한 정확한 판단을 내릴 수 있기 때문에 말하기 가 본격적으로 시작되는 유아기의 언어능력을 평가하는 중요 한 지표라 할 수 있다(J.-Y. Lee \& Kim, 2009). 수용어휘는 생애 초기부터 발달하기 시작하지만, 표현어휘의 경우 만 2 세 이후 부터 발달하기 때문에 아동이 말과 글에 사용된 어휘의 의미 를 이해할 수 있다 하더라도, 그것을 표현할 때 적절한 단어를 실제로 사용하지 못하는 경우가 많다(Zareva, Schwanenflugel, $\&$ Nikolova, 2005). 이에 영아기 이후의 언어능력을 평가함에 있어서 표현어휘는 중요한 언어지표라 할 수 있다. 이후 연령 이 증가하면서 아동은 많은 사람들과 대화를 하고 경험을 하 게 되면서 다양한 어휘를 배우게 된다. 더 나아가 이렇게 습득 한 어휘들 간의 유사점을 파악하여 범주화할 수 있으며, 이를 개념화할 수 있는 언어 능력이 발달하게 된다(Pence, Justice, \& Wiggins, 2008). Vygotskil, Hanfmann과 Vakar (1962)에 의하면 아동이 개념 형성을 위해 처음 시도하는 것은 다양한 대상들 을 체계화되지 않는 덩어리로 묶는 것이며, 이러한 덩어리들 은 점차 연령이 증가하고 경험이 쌓여감에 따라 적절하게 범 주화하고 추상화하여 상위 어휘로 개념화 할 수 있게 된다고 하였다. 즉, 아동 후기에 언어 개념화/범주화 능력은 언어발달 을 평가하는 중요한 언어지표라 할 수 있다. 종합하면 유아기 와 아동 후기 능력 측정은 발달 과정에서 다른 접근 방법이 필 요함을 알 수 있다. 이에 본 연구는 자녀의 어휘발달을 측정하 기 위해 유아기는 자녀의 기본적 표현 어휘발달을 탐색하고, 연령이 증가하는 아동 후기는 범주화된 어휘들을 상위 어휘로 개념화하는 능력을 살펴보았다.

자녀의 언어발달에 있어 주요한 인적자원환경인 부모는 자 녀가 태어나 성장하면서 가장 많은 접촉과 상호작용을 하는 주 공급원으로, 양육과 관련된 부모의 행동이 자녀의 언어 발 달에 영향을 미친다는 것은 이미 일반적으로 받아들여지고
있는 개념이다(Bartle-Haring \& Sabatelli, 1998). 부모-자녀 적 절한 상호작용은 자녀가 언어적으로 건강한 기능을 할 수 있 도록 하며, 부적절한 양육행동은 자녀의 언어 능력을 향상시 킬 수 있는 기회를 상실하게 하기도 한다(Fitzgerald, Hadley, \& Rispoli, 2013). 그러나 아동 발달을 부모-자녀 관계적인 측면에 서 살펴본 기존의 연구들(Han \& Hong, 2000; J.-S. Lee \& Han, 2004)은 부모가 양육에 참여하는 정도보다 주로 부모의 전반 적인 양육행동이나 양육태도에 초점을 맞추었다. 즉, 양육행동 을 측정한 대부분의 측정도구가 양육행동에 관한 수행정도를 살펴보기보다는 심리적 경향성으로서의 속성을 지니고 있다 (H.-S. Kim, 2010). 다시 말해, 양육행동 관련 선행연구들(Yang $\&$ Bang, 2014)에서 정의되는 양육행동이란 현실적이고 실천적 인 역할과 수행에 초점을 두고 있음에도 불구하고 실제로 행동 화되지 않는 내용이 포함되기도 한다. 이에 본 연구는 부모의 양육 관련 행동의 수행 정도를 측정할 필요가 있다고 사료되 어, 부모-자녀가 함께 공유할 수 있는 언어 및 신체놀이 활동의 참여 빈도를 통해 부모의 양육 관련 행동을 살펴보았다.

먼저 부모-자녀의 언어활동을 살펴보면, 부모-자녀 언어활 동은 학자마다 다양하게 정의되고 평가 되어왔다. 과거에는 가정 내 보유한 도서의 수, 가정에 노출된 문해 자료 빈도 등과 같이 간접적인 언어 환경을 제공해 주는 것을 강조하였다면 보다 최근에는 자녀에게 이야기 들려주기, 도서관 가기, 함께 대화하기, 함께 책읽기 등 다양한 범위로 확장하여 살펴보고 있다(Umek, Podlesek, \& Fekonja, 2005). Hoff-Ginsberg (1991)는 부모와 유아기 자녀의 경우 일상생활에서 이루어지는 일반적 대화보다, 책읽기나 재미있는 이야기를 들려주는 상황에서 더 많은 언어적 상호작용을 한다고 강조하였다. Lewis, Sandilos, Hammer, Sawyer와 Méndez (2016)는 부모가 자녀에게 책을 읽 어주고, 이야기를 들려주고, 도서관에 방문하는 빈도는 자녀 에게 직접 언어를 가르쳐주는 것보다 자녀의 언어능력에 긍정 적 영향을 미친다고 주장하고 있다. 이러한 활동들은 유아가 많은 책들에 노출되고 다양한 어휘들을 습득할 수 있도록 도 와줌으로써 유아의 표현어휘능력을 촉진한다(Sénéchal, Paga, Lever, \& Ouellette, 2008). 이러한 의미에서 본 연구는 부모-자 녀 언어활동을 책읽기 활동, 이야기 들려주기, 도서관 가기로 분류하여 각 활동에 대한 부모-자녀 참여 정도를 살펴보았다.

다음으로 자녀의 어휘발달에 영향을 미칠 수 있는 부모-자 녀 신체놀이 활동에 대해 살펴보면, 신체놀이 활동은 아동이 자신과 환경과의 관계를 이해하는데 중요한 역할을 하며 함 께 놀이하는 타인과의 상호작용을 통해 사회에 필요한 지식 과 능력을 발달시킨다(Fein, 1918). 더욱이 표현능력이 풍부하 
지 못한 유아의 경우 신체놀이 활동 참여는 언어 발달과 의사 소통 향상에 좋은 수단이 된다(Hickman, 1981). 신체놀이 활 동 참여는 새로운 언어의 생성을 자극하며, 새로운 어휘와 의 미가 소개되고 의사소통을 유도함으로써 언어적 사고를 고 취시킨다(Levy, 1984). 또한 유,아동기 자녀는 다양한 신체놀 이 활동 중 부모와 함께 하는 신체놀이 활동을 가장 선호한다 (Solter, 2013). Tomlinson과 Masuhara (2009)는 유아는 바깥에 서 신체 놀이 활동을 통해 게임 규칙에 대한 설명을 읽고 들으 면서 언어발달이 자연스럽게 이루어지며, 함께 놀이하는 타인 과 자연스럽게 대화를 나누는 것만으로도 언어발달을 이룰 수 있다 강조한다. 실외 바깥놀이 외에도 S. Kim과 Kwak (2015)의 연구에 따르면 가정에서 부모와 함께 실내에서 소근육 운동을 함께 하는 빈도는 대근육 운동보다 표현언어를 비롯한 유아의 전반적 언어발달에 더 많은 영향을 미치는 것으로 나타났다. 이에 본 연구는 부모-자녀 신체 놀이활동을 실외와 실내로 구 분하여 참여 정도를 살펴보았다.

또한 지금까지의 많은 선행연구들은 주로 횡단적 연구설계 를 통해 동일 시점의 변인들 간의 관계를 살펴보았다면, 종단 적 연구설계의 경우 각 연구변인들의 안정성과 시간의 흐름 에 따른 변인들 간 상호교류적 영향 및 종단적 효과를 살펴볼 수 있다는 측면에서 유용하다. 이러한 측면을 바탕으로 본 연 구 또한 연구변인들의 시간의 흐름에 따른 안정성과 상호교 류관계 및 종단적 효과를 파악하기 위한 검증을 실시하였다. 따라서 본 연구는 종단적 연구설계를 통해 부모-자녀 언어/신 체놀이 활동 참여와 자녀의 어휘발달의 안정성을 살펴보았 으며, Sameroff (2009)의 상호교류모델을 적용하여 유아기 부 모-자녀 언어/신체놀이 활동 참여와 자녀의 어휘발달 간의 관 계에서 각 변인이 상호 어떻게 영향을 미치는지를 살펴보았 다. 마지막으로 부모-자녀가 함께 경험하는 유아기 경험이 이 후 아동 후기 자녀의 발달 특성에 장기적인 영향을 미친다 는 선행연구를 바탕으로(Sénéchal et al., 2008; Sy, Gottfried, \& Gottfried, 2013), 유아기 시점의 부모-자녀 언어/신체놀이 활 동 참여가 이후 아동 후기 자녀 어휘능력 발달에 영향을 미치 는 종단적 효과를 살펴보았다. 이를 통해 유아기 부모-자녀 간 의 상호적 영향과 유아기 부모의 언어/신체놀이 활동에 관한 초기 양육참여 정도가 이후 아동 후기 자녀의 어휘능력과 같 은 발달 특성에 미치는 종단적 부모 효과를 확인함으로써, 자 녀의 긍정적 발달을 위한 부모의 초기 양육 참여의 중요성을 강조하고자 하였다.

더욱이 본 연구는 부모-자녀 언어/신체놀이 활동 참여와 자 녀의 어휘발달 간의 관계를 살펴보는데 있어서 가구소득수준
과 자녀의 인지능력을 통제하였다. 가구소득수준은 부모의 양 육 행동, 정서상태, 양육 스트레스와 같은 양육 관련 요인에 영 향을 미치고 있음을 많은 연구를 통해 보고되고 있다. 가정의 사회경제적 수준을 고려하지 않을 경우 특정 변수의 효과가 과소 또는 과대 추정될 수 있으며(Schmidt \& Sevak, 2006), 가 정의 사회경제적 수준은 부모의 정서적, 인지적, 행동적 상태 에 영향을 미치고, 이는 부모의 양육 관련 행동, 자녀와의 상호 작용 활동 및 자녀의 발달적 측면까지 영향을 미칠 수 있음을 많은 선행연구에서 보고하고 있다(Kwak, Yoo, \& Kim, 2007). 또한 인지발달이론을 주장한 Piaget는 감각운동기의 아동은 어떤 사물을 명명하기 앞서 사고하는 것이 명확하며, 이는 알 고 있는 것을 전달하는 것이기에 언어 발달이 이루어지기 전 에 사고(Smith \& Cowie, 1991)가 이루어진다고 강조한다. 이러 한 관점은 언어는 사고를 논리적으로 할 수 있도록 돕는 수단 으로 간주하였으며, 인지발달을 토대로 언어발달이 이루어짐 을 의미한다. 또한 자녀의 인지능력은 부모의 양육관련 행동 에도 영향을 미침을 일부 선행연구를 통해 보고되고 있다. 즉, 부모의 상호작용 행동은 자녀의 인지 수준에 따라 달라지는데 (Rogoff, Ellis, \& Gardner, 1984), 유아들의 인지 능력에 따라 부 모의 행동과 도움이 달라지는지 살펴본 결과 유아들이 과제 를 해결하는 인지 능력 수준이 높을 경우 부모들은 도움의 양 을 줄이거나 덜 구체적인 유형의 도움을 제공한다(Kermani \& Brenner, 2000). 이에 본 연구에서는 가구소득수준과 자녀의 인지능력을 통제하였다.

마지막으로 본 연구는 영국 밀레니엄 코호트 연구 (Millennium Cohort Study [MCS]) 데이터를 사용하여 부모-자 녀 언어/신체놀이 활동 참여와 자녀 어휘발달 간의 관계를 살 펴보았다. 본 데이터와 관련하여 서구 문화와 동양 문화라 는 문화적 차이의 가능성이 존재하지만 맞벌이 가정의 증가 와 아버지 양육 참여 증가 등 서구 문화와 비슷해지고 있는 한 국의 문화적 맥락을 고려해볼 때 한국의 부모-자녀 관계 증진 을 위한 중요한 교육적 시사점을 제공할 것으로 사료된다. 또 한 동,서양의 부모 양육행동을 비교한 연구(Y. Choi, Kim, Kim, $\&$ Park, 2013)에서는 한국과 서구 문화 부모들의 양육 관련 특 성은 긍정적 상관 관계가 있음을 보고하였다. 즉, 한국과 서구 문화 모두 부모의 긍정적 양육 참여 활동이 많을수록 또한 민 감한 양육행동을 보일수록 자녀 발달에 긍정적 효과가 있었 다(Y. Choi et al., 2013; Jang \& Lim, 2013). 이는 부모의 양육 관 련 행동은 범문화적으로 공유되며, 부모의 양육 참여, 온정성 과 같은 양육행동은 동,서양을 막론하고 보편적으로 강조되 는 긍정적 양육 요인이라 할 수 있다. 따라서 부모-자녀 언어/ 
신체놀이 활동 참여 경험이 서구 문화 뿐 만 아니라 한국 문화 에서도 공통적으로 인지하고 있는 중요한 양육 요인임을 유추 해 볼 때, 영국 데이터를 사용해 부모-자녀 언어/신체놀이 활 동 참여와 자녀 어휘발달 간의 관계를 살펴본 본 연구는 부모 의 양육 참여증가, 자녀의 긍정적 발달과 관련하여 한국 문화 에도 의미 있는 함의를 제공할 것으로 기대할 수 있다. 앞에서 논의된 연구의 필요성을 토대로 본 연구에서 살펴보고자 하 는 연구문제는 다음과 같다.

\section{연구문제 1}

부모-자녀의 언어 및 신체놀이 활동 참여와 자녀의 어휘발달 은 어떠한 관계를 갖는가?

\section{연구문제 2}

부모-자녀의 언어활동 참여와 자녀의 어휘발달은 시간의 흐 름에 따라 상호 및 종단적으로 영향을 미치는가?

\section{연구문제 3}

유아기 부모-자녀의 신체놀이 활동 참여와 자녀의 어휘발달 은 시간의 흐름에 따라 상호 및 종단적으로 영향을 미치는가?

\section{Methods}

\section{연구대상}

본 연구는 영국을 대표하는 5개의 코호트 자료 중 '밀레니엄 코호트 연구(MCS)' 자료를 사용하였다. 밀레니엄 코호트 연 구는 2000년도에 잉글랜드, 스코틀랜드, 웨일즈 그리고 노던 아일랜드에 있는 약 400 여개의 도시에서 태어난 약 19,000 명 의 아동과 그 부모를 대상으로 한 영국의 대표적 코호트 연구 이다. 본 코호트 연구는 2000년도에 태어난 아동을 대상으로 시작한 연구로 아동의 신체적, 정서사회, 인지, 행동발달을 비 롯하여 그들의 일상생활과 경험들을 추적 조사하였을 뿐만 아 니라, 코호트 아동의 경제적 수준, 부모의 양육행동, 가족생활 환경 등을 살펴보고 있으며, 이들의 건강한 발달을 위해 현재 까지도 추적조사를 진행하고 있다. 본 연구 자료를 사용하기 위해 영국 정부가 주관하는 'UK Data Service'에 코호트 자료 사용에 관한 연구계획서를 제출한 한 후, 심사를 거쳐 코호트 자료 사용 승인을 받았다.

본 연구의 연구대상은 유아기부터 아동 후기까지의 시기
로 유아기의 경험이 아동 후기까지 영향을 미칠 수 있음을 확 인하고자 선정하였다. 특히, 만 3 세는 표현 어휘력이 발달하는 시기로(Glazer \& Burke, 1994), 다양한 어휘들을 이해하고 표 현하게 된다. 이후 만 5세 경이 되면 표현언어능력의 발달로 타인과의 상호작용이 수월해지면서 부모와 다양한 활동을 할 기회가 많아진다. 무엇보다 유아기때 부모의 상호작용 활동참 여가 부족한 자녀들의 경우 연령이 증가할수록 언어능력에 어 려움을 겪을 수 있다는 연구결과(Rhee, Lee, Kim, \& Jun, 2008) 를 토대로 유아기인 만 3세(T1), 만 5세(T2)와 아동 후기 11세 (T3)를 연구대상으로 T1 (만 3세), T2 (만 5세), T3 (만 11세)인 세 시점 간 부모-자녀 활동 참여와 자녀의 어휘발달의 종단적 변화를 탐구하고자 한다.

본 연구의 참가자는 만 3 세, 5세, 11 세 시기의 자녀들과 그 자녀들을 양육하는 부모들이다. 본 연구의 만 3세(T1) 조사에 참여한 가족은 총 15,590 쌍이었고 이 중 669 쌍이 탈락하여 만 5세(T2) 조사에서는 14,921 쌍이 참여하였다. 마지막으로 11 세(T3) 조사에는 1,733 쌍이 탈락하여 총 13,188 쌍이 참여하 였다. 약 8 년에 거쳐 조사에 모두 참여한 부모 및 아동들과 $\mathrm{T} 1$ 조사에만 참여하고 탈락한 부모 및 아동 $(2,402$ 쌍) 간의 차이 를 사회 인구학적 변인을 중심으로 살펴본 결과, 아버지의 교 육수준 $\left(\chi^{2}=-29.38, p<.001\right)$, 어머니의 교육수준 $\left(\chi^{2}=-32.45\right.$, $p<.001)$ 과 부모의 맞벌이 $\left(\chi^{2}=3.57, p<.05\right)$ 에서 유의한 차이 가 나타났다. 즉, 부모의 교육수준이 낮을수록, 맞벌이 부모 일 수록 탈락한 경우가 많았다. 본 연구에서는 탈락자들을 제외한 13,188 쌍 중 한부모 가족 3,645쌍, 문항에 성실히 응답하지 않 은 경우(39쌍), 이상치가 포함된 경우(84쌍), 총 3,768쌍을 제외 한 양부모 가족과 자녀 9,420쌍을 분석대상으로 선정하였다.

\section{연구도구}

\section{부모-자녀 언어활동 참여}

본 연구는 유아기 부모-자녀의 언어활동을 측정하기 위해 “책 읽기', ‘도서관 가기', ‘이야기 들려주기'라는 문항을 구성하였 다. 각각의 문항은 “얼마나 자주 자녀와 도서관에 가는가?”, “얼마나 자주 자녀에게 이야기를 들려주는가?”, "얼마나 자주 책을 읽는가.”로 질문한다. 책읽기와 이야기 나누기 문항은 전 혀 하지 않는다(1점), 한 달에 한 번 미만 한다(2점), 한 달에 한 두 번한다(3점), 일주일에 한 두 번 한다(4점), 일주일에 여러 번 한다(5점), 매일 또는 거의 매일 한다(6점)로 측정하며 점수 가 높을수록 자녀와 언어활동을 자주하고 있음을 의미하며, 
도서관 가기 문항은 전혀 가지 않는다(1점), 특별한 경우(2점), 한 달에 한 번(3점), 2주일에 한 번(4점), 일주일에 한 번(5점) 으로 측정하며 점수가 높을수록 자녀와 언어활동을 자주하고 있음을 의미한다. 본 측정도구의 신뢰도인 Cronbach's $\alpha$ 계수 는 $\mathrm{T} 1$ 에서 .63 (부), .62 (모), T2에서 .64 (부), .61 (모)이다.

\section{부모-자녀 신체 놀이활동 참여}

부모-자녀의 신체놀이 활동을 측정하기 위해 실내외 신체 놀 이 활동으로 문항을 구성하였다. 각 문항은 "얼마나 자주 자녀 와 실내에서 놀이를 하는가?”와 “얼마나 자주 자녀와 바깥에 서 운동 또는 신체적 놀이를 하는가?”로 질문한다. 각 문항은 전혀 하지 않는다(1점), 한 달에 한 번 미만 한다(2점), 한 달에 한 두 번한다(3점), 일주일에 한 두 번 한다(4점), 일주일에 여 러 번 한다(5점), 매일 또는 거의 매일 한다(6점)로 점수가 높 을수록 자녀와 신체놀이 활동을 자주하고 있음을 의미하도록 처리하였다. 각 시점의 Cronbach's $\alpha$ 계수는 T1에서 .64 (부), .65 (모), T2에서 .65 (부), .66 (모)로 나타났다.

\section{어휘발달}

자녀의 어휘발달은 연령마다 언어발달 과업이 다른 시기이기 때문에 British Ability Scales (BAS) 언어능력 측정 도구에서 각 연령별 발달 단계에 맞춰 구성된 측정 도구를 사용하였다. 유 아기 T1 (만 3세), T2 (만 5세)를 대상으로 측정한 도구는 BAS 에서 '어휘 명명화'이며, T3 (만 11세)는 BAS에서 '어휘 유사도' 로 측정하였다.

어휘 명명화는 아동의 표현 언어를 측정하기 위한 도구이 다. 연구자가 화면에 나타난 그림을 유아에게 보여준 후 코호 트 연구원은 “이것이 무엇이지?” 라고 질문하고 그것의 이름을 아동이 스스로 맞추도록 한다. 총 36 문항으로 이루어져 있으 며, 문항 난이도는 점점 더 어려워진다. 점수는 맞으면 1점, 틀 리면 0점을 부여한다. 본 연구는 연령별로 점수를 산출한 백분 위 점수를 사용하여 분석하였다. 언어 유사도 측정도구는 11 세 아동의 범주화/개념화 능력을 바탕으로 단어를 명명할 수 있 는 능력을 측정하기 위한 도구이다. 연구자가 아동에게 3 개의 단어들을 읽어준 후 아동은 이 단어들의 공통된 개념을 연구 자에게 명명화한다. 예를 들어, 'Banana, Apple, Orange' 세 단어 를 읽어주고, 세 단어의 유사점을 맞추도록 한다. 문항 수는 총 36 문항이며 문항 난이도는 점점 더 복잡해지고 어려워진다. 점 수는 맞으면 1점, 틀리면 0 점을 부여한다. 채점은 세 단어가 공
통적으로 가지고 있는 유사성을 말해야 정답이며, 너무 포괄적 으로 대답할 경우 오답으로 간주한다(예: tiger, lion, bear = 정답 [animal], 오답[They all have legs]). 마지막으로 본 연구는 연령별 로 점수를 산출한 백분위 점수를 사용하여 분석하였다.

\section{통제 변인}

본 연구는 부모-자녀 언어활동 및 신체놀이 활동 참여와 자녀 의 어휘발달에 영향을 미칠 수 있다고 판단되는 가구소득수준 과 자녀의 인지능력을 통제변수로 선정하였다. 가구 소득 수 준의 경우 각 시점 별 물가상승률 등을 고려하여 본 데이터에 서 각 해마다 소득수준에 따라 $10 \%$ 나눈 지표를 활용하여, 소 득을 5 분위로 나눈 뒤, 소득 1,2 분위는 '하위소득분위', 소득 3 , 4 분위는 ‘중위소득분위’로, 소득 5 분위는 '상위소득분위’로 구 분하여 통제하였다. 자녀 인지능력의 경우 연령별로 측정하 고자 하는 인지능력이 다르기 때문에 각 시점별로 측정한 인 지능력을 통제하였으며, 모든 점수는 표준 점수를 적용, 투입 하였다. 유아기 $\mathrm{T} 1,2$ 시점의 경우 유아기 인지능력을 측정한 BAS 의 'Pattern Construction'은 공간적 표상능력을 평가하는 도구로 스크린 화면에 검정, 노란색의 큐브가 섞인 모형이 제 시되면 유아는 제시된 모형과 똑같은 모형을 주어진 검정, 노 란색 큐브로 만든다. 총 26문항으로 구성되어 있으며, 점수는 맞으면 1점, 틀리면 0점을 부여한다. T3 아동 후기는 CANTAB 의 작업기억을 측정하는 도구로 총 12 문항으로 구성되었다.

\section{자료분석}

본 연구의 분석은 SPSS 22.0 (IBM Co., Armonk, NY)과 AMOS 21.0 (IBM Co., Armonk, NY)을 사용하여 다음과 같은 절차 로 진행하였다. 첫째, 각 변인의 평균 및 표준편차 등의 기초 통계를 살펴본 뒤, 각 변인들 간의 상관관계를 파악하기 위해 Pearson의 적률상관계수를 산출하였다. 둘째, 부모-자녀 언어/ 신체놀이 활동 참여를 측정하는 측정도구 지표들에 대한 타당 성을 확인하기 위해 확인적 요인분석을 실시하였다. 다음으로 부모-자녀 활동(언어활동, 신체놀이 활동)과 자녀의 어휘능력 이 종단적 발달과정에서 얼마나 안정적인지 살펴보았으며, 부 모-자녀 활동 참여가 자녀의 어휘발달에 어떠한 영향을 미치 는지, 반대로 자녀의 어휘발달이 시간의 흐름에 따라 부모-자 녀 활동에 어떠한 영향을 미치는지 자기회귀교차지연분석을 통해 상호교류관계를 살펴보았다. 마지막으로 유아기 부모자녀 언어/신체놀이 활동 참여가 자녀 어휘발달에 미치는 종 
단적 효과를 함께 살펴보았다.

\section{Results}

\section{연구변인들의 기초분석}

본 연구는 부모-자녀 언어/신체놀이 활동 참여와 자녀 어휘발 달 간의 상호교류관계를 검증하기 앞서 우선 부모-자녀 언어/ 신체놀이 활동 참여 잠재변인들을 측정하는 관측변인들과 자 녀 어휘발달의 상관관계를 분석하였다. 부모의 언어/신체놀 이 활동 참여와 자녀의 언어능력의 상관관계를 각 시점 내와 각 시점 간으로 구분해서 살펴보면 Table 1,2 와 같다. 우선 부 모-자녀 언어활동 참여 정도와 자녀의 어휘발달 간의 각 시 점 내 상관 관계는 모든 변인에서 유의하였다([T1]: $r s=.236$ $\sim .371, p<.01$, [T2]: $r s=.227 \sim .296, p<.01)$. 다음으로, 각 시 점 간 상관 관계와 관련하여 모든 연구변인들이 서로 유의하
였다( $r s=.212 \sim .543, p<.01, p<.001) .11$ 세 어휘발달과 연구 변인들과의 상관관계도 모두 유의미하였다 $(r s=.186 \sim .401, p$ $<.01, p<.001)$.

부모-자녀 신체놀이 활동 참여 관측 변인들과 자녀의 어휘 발달의 상관관계를 각 시점 내와 각 시점 간으로 구분해서 살 펴보면 다음과 같다. 각 시점 내 변인들 간의 상관관계는 모든 변인에서 상관관계를 보였으며([T1]: $r s=.209 \sim .298, p<.01$ ), [T2]: $r s=.218 \sim .274, p<.01)$, 각 시점 간 상관관계도 모든 연 구변인들이 서로 유의한 상관 관계를 보였다( $r s=.129 \sim .457$, $p<.05, p<.01, p<.001) .11$ 세의 어휘발달과 연구 변인들과 의 상관관계는 모든 변인에서 유의미하였다( $r s=.125 \sim .401, p$ $<.05, p<.01, p<.001)$.

\section{부모-자녀 언어활동 참여와 자녀 어휘발달 간의 상호 교류 및 종단적 관계}

본 연구는 부모-자녀 언어/신체 놀이활동 참여와 자녀 어휘발

\section{Table 1}

Correlations Among the Research Variables (Language Activity)

\begin{tabular}{|c|c|c|c|c|c|c|c|c|}
\hline & Variables & 1 & 2 & 3 & 4 & 5 & 6 & 7 \\
\hline \multirow[t]{2}{*}{$\mathrm{T} 1$} & 1 Father-children LA & - & & & & & & \\
\hline & 2 Mother-children LA & $.371^{* *}$ & - & & & & & \\
\hline \multirow[t]{2}{*}{$\mathrm{T} 2$} & 4 Father-children LA & $.543^{* * *}$ & $.308^{* *}$ & $.254^{* *}$ & - & & & \\
\hline & 5 Mother-children LA & $.357^{* *}$ & $.454^{* * *}$ & $.259^{* *}$ & $.296^{* *}$ & - & & \\
\hline $\mathrm{T} 3$ & 7 Vocabulary development & $.212^{* *}$ & $.196^{* *}$ & $.382^{* *}$ & $.186^{* *}$ & $.234^{* *}$ & $.401^{* * *}$ & - \\
\hline
\end{tabular}

Note. $N=9,420$. LA = language ability.

${ }^{* *} p<.01 .{ }^{* * *} p<.001$.

Table 2

Correlations Among the Research Variables (Physical Play Activity)

\begin{tabular}{|c|c|c|c|c|c|c|c|c|}
\hline & Variables & 1 & 2 & 3 & 4 & 5 & 6 & 7 \\
\hline \multirow[t]{2}{*}{$\overline{\mathrm{T} 1}$} & 1 Father-children PA & - & & & & & & \\
\hline & 2 Mother-children PA & $.298^{* *}$ & - & & & & & \\
\hline \multirow[t]{2}{*}{$\mathrm{T} 2$} & 4 Father-children PA & $.457^{* * *}$ & $.206^{* *}$ & $.251^{* *}$ & - & & & \\
\hline & 5 Mother-children PA & $.215^{* *}$ & $.422^{* * *}$ & $.166^{* *}$ & $.218^{* *}$ & - & & \\
\hline $\mathrm{T} 3$ & 7 Vocabulary development & $.125^{*}$ & $.198^{* *}$ & $.382^{* *}$ & $.232^{* *}$ & $.233^{* *}$ & $.401^{* * *}$ & - \\
\hline
\end{tabular}

Note. $N=9,420 . \mathrm{PA}=$ physical play activity.

${ }^{*} p<.05 .{ }^{* *} p<.01 .{ }^{* * *} p<.001$. 
Table 3

Model Fit Indices of Research Model (Parents-Children Language Acitivity)

\begin{tabular}{|c|c|c|c|c|c|c|}
\hline & $\chi^{2}$ & $d f$ & TLI & CFI & RMSEA & $\Delta \chi^{2}(\Delta d f)$ \\
\hline 2 & $4395.519^{* * *}$ & 175 & .971 & .980 & .030 & $18.485^{* * *}(2)$ \\
\hline 4 & $4417.430^{* * *}$ & 178 & .971 & .980 & .030 & $11.023^{* *}(1)$ \\
\hline 5 & $4421.570^{* * *}$ & 179 & .971 & .980 & .030 & $4.140^{*}(1)$ \\
\hline
\end{tabular}

${ }^{*} p<.05 .{ }^{* *} p<.01 .{ }^{* * *} p<.001$.

Table 4

Path Coefficients of Research Model (Parents-Children Language Acitivity)

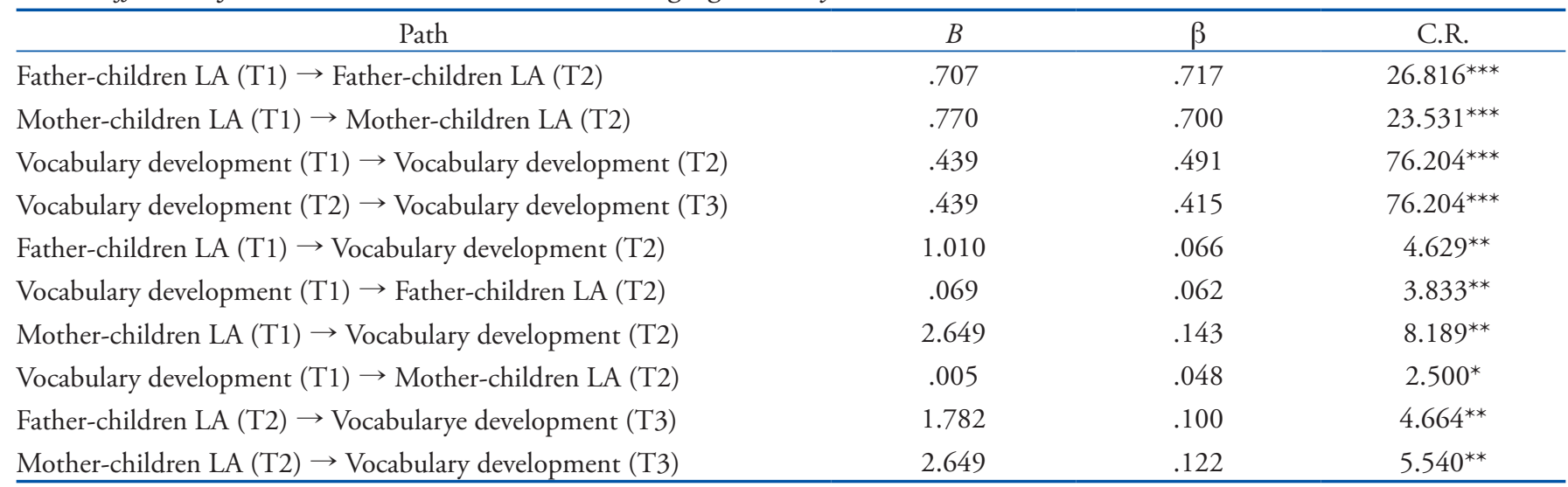

${ }^{*} p<.05 .{ }^{* *} p<.01 .{ }^{* * *} p<.001$.

달 간의 상호적 영향과 종단적 관계를 자기회귀 교차지연 모 델 분석을 통해 살펴보았다. 이러한 모델을 분석하려면 먼저 각 시점에서 측정하는 개념이 동일한지 확인하기 위해 잠재변 인에서 측정변인으로의 요인부하량을 제약하는 측정동일성 을 검증하였다. 그 다음으로 각 변인 간 경로계수를 제약하여 시간의 흐름에 따라 회귀계수가 동일한지 검토하는 구조 동일 성을 검증하였다. 부모-자녀 언어활동 참여와 자녀의 어휘발 달의 안정성 및 상호적 영향을 살펴보기 위해 6 개의 모형 중 최적의 모형을 찾아보고자 모형 간 적합도를 순차적으로 비교 하였다. 각 모형은 서로 내재된 관계이므로 두 모형의 자유도 차이와 $\chi^{2}$ 값의 차이가 유의한지 검증하는 $\chi^{2}$ 차이 검증을 적용 하여 그 차이가 유의하지 않은 경우 동일성이 성립된 것으로 본다. 그러나 $\chi^{2}$ 값의 경우 표본의 크기가 큰 경우 쉽게 유의미 한 결과가 도출될 수 있으므로 TLI, CFI 및 RMSEA를 함께 고 려하였는데, TLI 값이 .02이상 작아지지 않았거나, CFI 값이 .01 이상 작아지지 않거나 혹은 RMSEA 값이 .015이상 커지지 않았을 때 두 모형의 차이가 유의하지 않은 것으로 보고 동일 성이 성립되었다고 해석하였다.
먼저 측정동일성을 살펴보면, 비제약모형인 모형 1과 모형 2 는 $\chi^{2}$ 의 값 차이가 통계적으로 유의하였으나 $\left(\Delta \chi^{2}=18.485, \Delta\right.$ $d f=2, p<.001), \mathrm{TLI}, \mathrm{CFI}$ 및 RMSEA 값의 차이가 거의 나타나 지 않았다. 모형 3 과 모형 2 의 $\mathrm{X}^{2}$ 값의 차이는 통계적으로 유의 하였으나 $\left(\Delta \chi^{2}=10.888, \Delta d f=2, p<.001\right)$, TLI, CFI 및 RMSEA 값의 차이가 나타나지 않았다. 모형 4 와 모형 3 의 $\chi^{2}$ 값의 차이 도 통계적으로 유의하였으나 $\left(\Delta \chi^{2}=11.023, \Delta d f=1, p<.01\right)$, TLI, CFI 및 RMSEA 값의 차이가 나타나지 않아 두 모형의 차이가 유의하지 않음이 확인되어 동일성이 성립되었다. 한 편, 교차회귀계수의 구조동일성의 경우, 모형 5와 4 간의 $\chi^{2}$ 차 이는 통계적으로 유의하였으나 $\left(\Delta \chi^{2}=4.140, \Delta d f=1, p<.05\right)$, TLI, CFI 및 RMSEA 값이 모두 차이가 나타나지 않았다(모형 5와 4: $\Delta \mathrm{TLI}=.000, \Delta \mathrm{CFI}=.000, \Delta \mathrm{RMSEA}=.000)$. 모형 6 과 5 간의 $\chi^{2}$ 차이는 통계적으로 유의하지 않았으며 $\left(\Delta \chi^{2}=1.807, \Delta\right.$ $d f=1, p>$.05), TLI, CFI 및 RMSEA 값도 모두 차이가 나타나 지 않았다 $(\Delta \mathrm{TLI}=.000, \Delta \mathrm{CFI}=.000, \Delta \mathrm{RMSEA}=.000)$. 즉, 시 간의 흐름에 따라 부모-자녀 언어활동 참여 측정변인들이 각 각에 대한 해석을 동일하게 하는 것으로 나타나 측정동일성을 


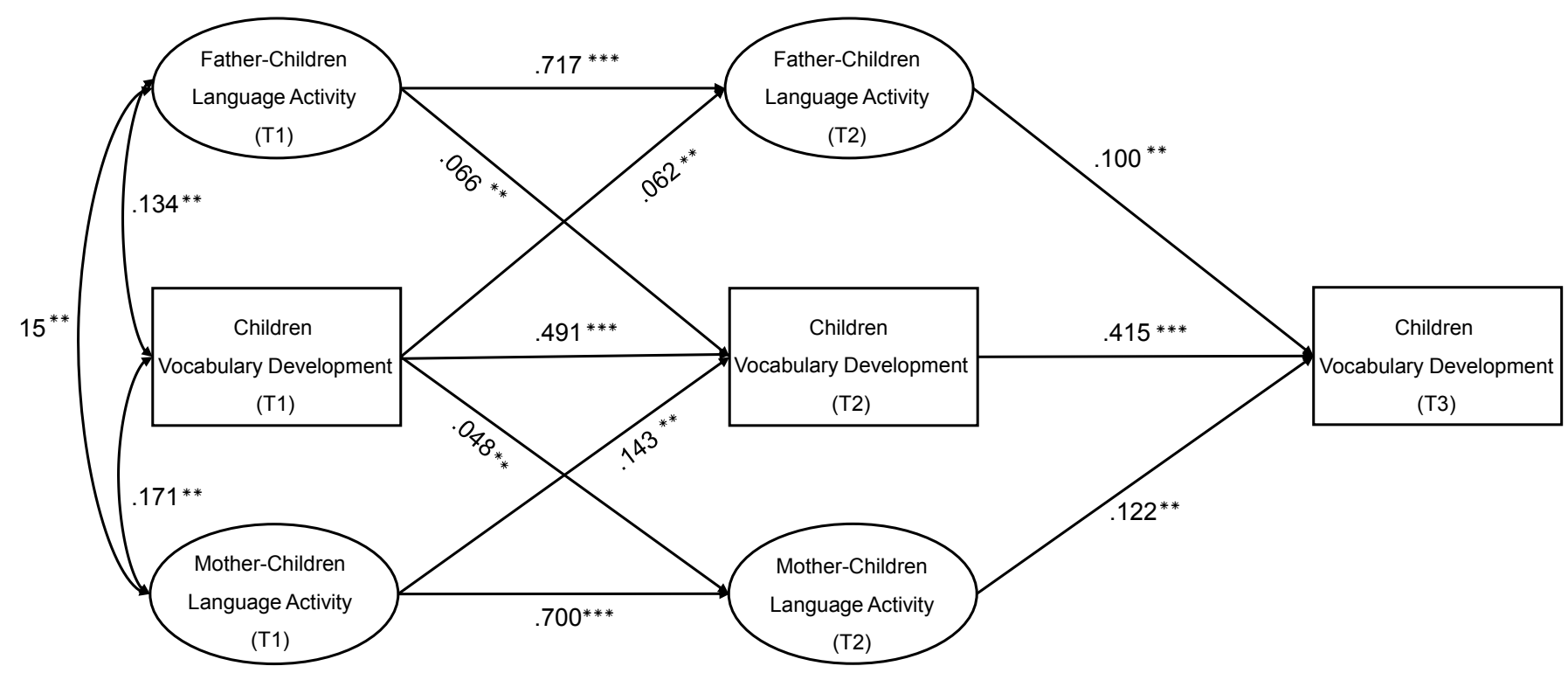

Figure 1. Autoregressive cross-lagged model of parents- children language activity and vocabulary development (standardized coefficients).

${ }^{* *} p<.01 .{ }^{* * *} p<.001$.

충족하였으며, 자녀 어휘발달의 자기회귀계수와 부모-자녀 언어활동 참여가 자녀 어휘발달에 영향을 미치는 회귀계수가 시간에 따라 동일하다는 구조동일성을 충족하는 것으로 나타 났다. 결과적으로, 측정동일성과 구조동일성 모두 충족된 것 으로 확인된 모형 6을 최종 모형으로 채택하여 구조계수를 추 정하였으며, 그 결과는 Table 3 과 같다.

먼저 부모-자녀 언어활동 참여와 자녀 어휘발달의 연속성 과 관련하여 자기회귀계수를 살펴보면, 부-자녀 간 언어활동 의 경우 $\mathrm{T} 1$ 에서 $\mathrm{T} 2$ 로 가는 경로 $(\beta=.717, p<.001)$ 는 유의하 였으며, 모-자녀 간 언어활동의 경우 $\mathrm{T} 1$ 에서 $\mathrm{T} 2$ 로 가는 경로 $(\beta=.700, p<.001)$ 도 유의하였다. 자녀의 어휘발달의 경우 $\mathrm{T} 1$ 에서 T2 $(\beta=.491, p<.001), \mathrm{T} 2$ 에서 T3 $(\beta=.415, p<.001)$ 또한 유의하였다. 즉, 부모의 언어활동 참여와 자녀의 어휘발달은 시간의 흐름에 따라 모두 안정적으로 나타났다.

다음으로, 부모-자녀 언어활동 참여와 자녀의 어휘발달 간 의 교류적 관계와 관련하여 교차지연계수를 살펴보면 다음과 같다. 부-자녀 간 언어활동 참여(T1)가 자녀의 어휘발달(T2) 에 미치는 영향 $(\beta=.066, p<.01)$ 은 유의하였으며, 모-자녀 간 언어활동 참여(T1)가 자녀의 어휘발달(T2)에 미치는 영향 $(\beta$ $=.143, p<.01)$ 도 유의하였다. 자녀의 어휘발달이 부모-자녀 언어활동에 미치는 경로는 이전 시점의 자녀 어휘발달 (T1)이 이후 시점의 부-자녀 언어활동(T2)에 미치는 경로 $(\beta=.062, p$ $<.01)$, 자녀 어휘발달(T1)이 모-자녀 어휘발달(T2)에 미치는
경로 $(\beta=.048, p<.05)$ 모두 유의하였다. 즉, 만 3세(T1)에서 부모-자녀 언어활동 참여가 많을수록 만 5세(T2) 자녀의 어휘 발달이 높았으며, 만 3세(T1) 자녀의 어휘발달 수준은 만 5세 (T2)에서 부모-자녀 간 언어활동에 영향을 미쳤다. 마지막으 로 부모- 만 5 세 자녀 간 언어활동 참여는 11 세 자녀의 어휘발 달에 모두 유의미한 영향을 미쳤다(부: $\beta=.100, p<.01$, 모: $\beta$ $=.122, p<.01)$.

\section{부모-자녀 신체 놀이활동 참여와 자녀 어휘 발달 간의 상호 교류 및 종단적 관계}

본 연구는 부모-자녀 언어/신체 놀이 활동 참여와 자녀 어휘 발달 간의 상호적 영향과 종단적 관계를 자기회귀 교차지 연 모델 분석을 통해 살펴보았다. 먼저 측정동일성을 살펴보 면 비제약모형인 모형 1 과 모형 2는 $\chi^{2}$ 의 값 차이가 통계적으 로 유의하였지만 $\left(\Delta \chi^{2}=10.480, \Delta d f=1, p<.01\right)$, TLI, CFI 및 RMSEA 값의 차이가 나타나지 않았다. 모형 3과 모형 2의 $\chi^{2}$ 값의 차이는 통계적으로 유의하지 않았으며 $\left(\Delta \chi^{2}=0.421, \Delta d f\right.$ $=1, p>.05)$, TLI, CFI 및 RMSEA 값도 크게 차이가 나타나지 않았다. 모형 4 와 모형 3 의 $\chi^{2}$ 값의 차이도 통계적으로 유의하 였으나 $\left(\Delta \chi^{2}=20.784, \Delta d f=1, p<.001\right)$, TLI, CFI 및 RMSEA 값 도 차이가 나타나지 않아, 모형 간 차이가 유의하지 않은 것으 로 확인되어 동일성이 충족되었다. 교차회귀계수의 구조동일 
Table 5

Model Fit Indices of Research Model (Parents-Children Physical Play Acitivity)

\begin{tabular}{|c|c|c|c|c|c|c|}
\hline & $\chi^{2}$ & $d f$ & TLI & CFI & RMSEA & $\Delta \chi^{2}(\Delta d f)$ \\
\hline 1 & $2432.960^{* * *}$ & 101 & .980 & .988 & .029 & - \\
\hline 2 & $2443.440^{* * *}$ & 102 & .980 & .988 & .029 & $10.480^{* *}(1)$ \\
\hline 4 & $2464.645^{* * *}$ & 104 & .981 & .988 & .029 & $20.784^{* * *}(1)$ \\
\hline 5 & $2478.180^{* * *}$ & 105 & .981 & .988 & .029 & $13.535^{* * *}(1)$ \\
\hline
\end{tabular}

${ }^{* *} p<.01 .{ }^{* * *} p<.01$.

Table 6

Path Coefficients of Research Model (Parents-Children Physical Play Activity)

\begin{tabular}{|c|c|c|c|}
\hline Path & $B$ & $\beta$ & C.R. \\
\hline Father-children PA (T1) $\rightarrow$ Father-children PA (T2) & .686 & .649 & $37.246^{* * *}$ \\
\hline Mother-children PA (T1) $\rightarrow$ Mother-children PA (T2) & .644 & .587 & $38.745^{* * *}$ \\
\hline Vocabulary development (T2) $\rightarrow$ Vocabulary development (T3) & .439 & .415 & $76.204^{* * *}$ \\
\hline Father-children PA (T1) $\rightarrow$ Vocabulary development $(\mathrm{T} 2)$ & .449 & .021 & 1.585 \\
\hline Vocabulary development $(\mathrm{T} 1) \rightarrow$ Mother-children PA (T2) & .001 & .003 & 1.002 \\
\hline Father-children PA T2 $\rightarrow$ Vocabulary development T3 & .532 & .113 & $1.739^{* *}$ \\
\hline Mother-children PA T2 $\rightarrow$ Vocabulary development T3 & .996 & .084 & $5.243^{* *}$ \\
\hline
\end{tabular}

${ }^{* *} p<.01{ }^{* * *} p<.001$.

성의 경우, 모형 5 와 4 간의 $\chi^{2}$ 차이는 통계적으로 유의하였으 나 $\left(\Delta \chi^{2}=13.535, \Delta d f=1, p<.001\right)$, TLI, CFI 및 RMSEA 값의 차이가 나타나지 않았다 $(\Delta \mathrm{TLI}=.000, \Delta \mathrm{CFI}=.000, \Delta \mathrm{RMSEA}$ $=.000)$. 모형 6과 5간의 $\chi^{2}$ 차이는 통계적으로 유의하지 않았 으며 $\left(\Delta \chi^{2}=0.029, \Delta d f=1, p>.05\right)$, TLI, CFI 및 RMSEA 값도 같았다. 즉, 시간의 흐름에 따라 부모-자녀 신체놀이 활동 각 각에 대한 해석을 동일하게 하는 것으로 나타나 측정동일성을 충족하였으며, 자녀 어휘발달의 자기회귀계수와 부모-자녀 신체놀이 활동 참여가 자녀 어휘발달에 영향을 미치는 회귀계 수가 시간에 따라 동일하다는 구조동일성을 충족하는 것으로 나타났다. 결과적으로, 측정동일성과 구조동일성 모두 충족된 것으로 확인된 모형 6을 최종 모형으로 채택하여 구조계수를 추정하였으며, 그 결과는 Table 5와 같다.

다음으로 부모-자녀 신체 놀이활동 참여와 자녀 어휘발달 의 연속성과 관련하여 자기회귀계수를 살펴보면, 부-자녀 간 신체놀이 활동의 경우 $\mathrm{T} 1$ 에서 $\mathrm{T} 2$ 경로 $(\beta=.649, p<.001)$ 는 유 의하였으며, 모-자녀 간 신체놀이 활동의 경우 $\mathrm{T} 1$ 에서 $\mathrm{T} 2$ 경 로 $(\beta=.587, p<.001)$ 또한 유의하였다. 자녀의 어휘발달의 경
우 T1에서 T2 $(\beta=.491, p<.001)$, T2 에서 T3 $(\beta=.415, p<$ .001)로 모두 유의하였다. 즉, 부모-자녀 신체놀이 활동 참여와 자녀의 어휘발달은 시간의 흐름에 따라 모두 안정적으로 나타 났다.

부모-자녀 신체놀이 활동 참여와 자녀의 어휘발달 간의 교 류적 관계와 관련하여 교차지연계수를 살펴보면 다음과 같다. 부-자녀 간 신체놀이 활동 참여(T1)가 자녀의 어휘발달(T2)에 영향을 미치는 경로는 유의하지 않았지만, 모 - 자녀 간 신체놀 이 활동 참여(T1)가 자녀의 어휘발달(T2)에 미치는 영향 $(\beta=$ $.063, p<.01)$ 은 유의하였다. 반대로 자녀의 어휘발달이 부모자녀 신체놀이 활동에 미치는 경로는 자녀의 어휘발달(T1)이 부-자녀 간 신체놀이 활동 참여(T2)에 미치는 경로 $(\beta=.074, p$ $<.01)$ 는 유의하였지만, 자녀의 어휘발달(T1)이 모-자녀 간 신 체놀이 활동참여(T2)에 영향을 미치는 경로는 유의하지 않았 다. 즉, 만 3 세 시점(T1)에서 모-자녀 간 신체놀이 활동 참여 가 많을수록 만 5세(T2) 자녀의 어휘발달이 높았으며, 만 3세 (T1) 자녀의 어휘발달 수준은 만 5세(T2)의 부 - 자녀 간 신체 놀이 활동에 영향을 미쳤다. 마지막으로 부모-만 5세 자녀 간 


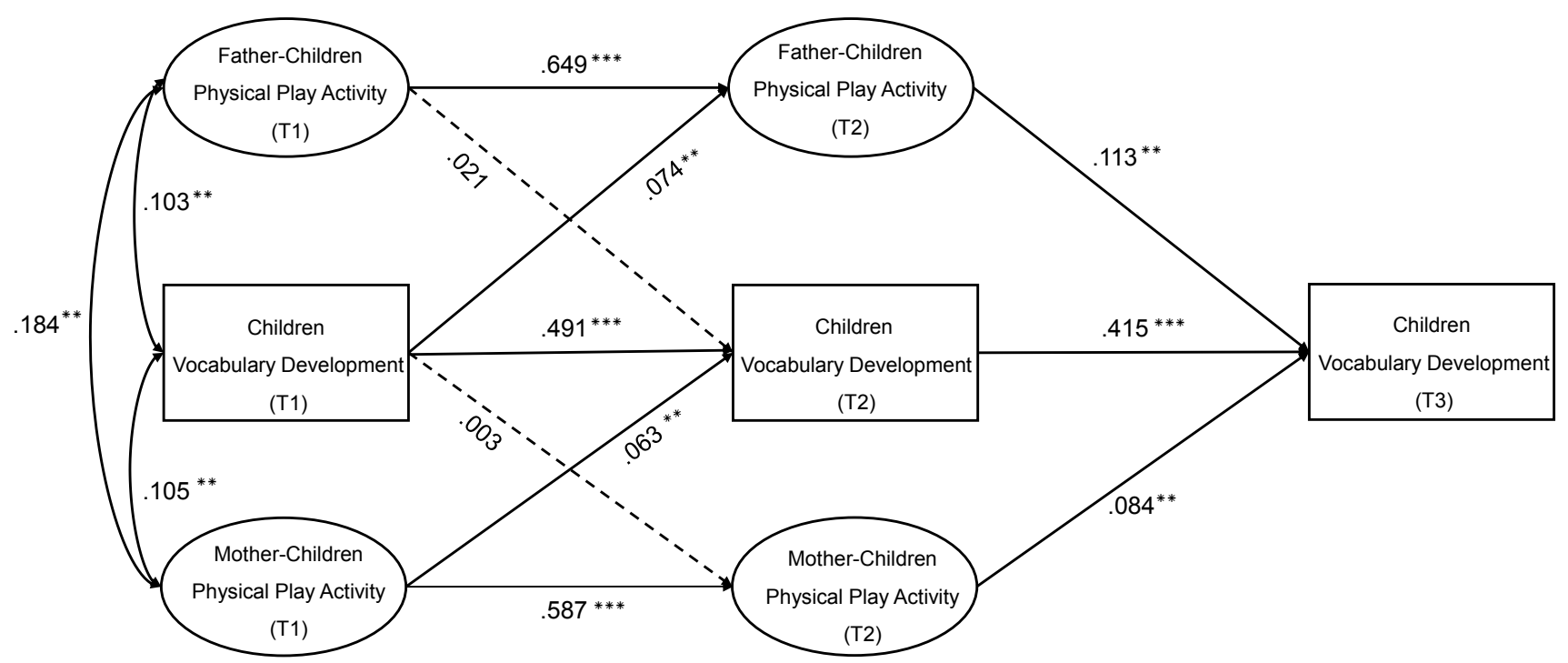

Figure 2. Autoregressive cross-lagged model of physical play activity and vocabulary development (standardized coefficients).

${ }^{* *} p<.01 .{ }^{* * *} p<.001$.

Table 7

Coefficients of Control Variables

\begin{tabular}{lc}
\hline \multicolumn{1}{c}{ Path } & $\beta$ \\
\hline $\mathrm{HIL} \rightarrow$ Father-children LA (T1) & $.245^{* * *}$ \\
$\mathrm{HIL} \rightarrow$ Mother-children LA (T1) & $.202^{* * *}$ \\
$\mathrm{HIL} \rightarrow$ Father-children PA (T1) & $.218^{* * *}$ \\
$\mathrm{HIL} \rightarrow$ Mother-children PA (T1) & $.236^{* * *}$ \\
$\mathrm{HIL} \rightarrow$ Vocabulary development (T1) & $.253^{* * *}$ \\
$\mathrm{HIL} \rightarrow$ Father-children LA (T2) & $.209^{* * *}$ \\
$\mathrm{HIL} \rightarrow$ Mother-children LA (T2) & $.149^{* * *}$ \\
$\mathrm{HIL} \rightarrow$ Father-children PA (T2) & $.211^{* * *}$ \\
$\mathrm{HIL} \rightarrow$ Mother-children PA (T2) & $.214^{* * *}$ \\
$\mathrm{HIL} \rightarrow$ Vocabulary development (T2) & $.230^{* * *}$ \\
$\mathrm{HIL} \rightarrow$ Vocabulary development (T3) & $.227^{* * *}$ \\
$\mathrm{CD} \rightarrow$ Father-children LA (T1) & $.070^{* *}$ \\
$\mathrm{CD} \rightarrow$ Mother-children LA (T1) & $.048^{*}$ \\
$\mathrm{CD} \rightarrow$ Father-children PA (T1) & $.071^{* *}$ \\
$\mathrm{CD} \rightarrow$ Mother-children PA (T1) & .021 \\
$\mathrm{CD} \rightarrow$ Vocabulary development (T1) & $.592^{* * *}$ \\
$\mathrm{CD} \rightarrow$ Father-children LA (T2) & $.067^{* *}$ \\
$\mathrm{CD} \rightarrow$ Mother-children LA (T2) & .028 \\
$\mathrm{CD} \rightarrow$ Father-children PA (T2) & $.069^{* *}$ \\
$\mathrm{CD} \rightarrow$ Mother-children PA (T2) & .022 \\
$\mathrm{CD} \rightarrow$ Vocabulary development (T2) & $.446^{* * *}$ \\
$\mathrm{CD} \rightarrow 5$ Vocabulary development (T3) & $.461^{* * *}$ \\
\hline$N$
\end{tabular}

Note. $N=9,420 . \mathrm{HIL}=$ home income level; LA = language activity; $\mathrm{PA}=$ physical play activity; $\mathrm{CD}=$ cognitive development. ${ }^{*} p<.05 .{ }^{* *} p<.01 .{ }^{* * *} p<.001$.
신체놀이 활동 참여가 11 세 자녀의 어휘발달에 미치는 영향 은 부모-자녀 신체놀이 활동(T2)이 자녀의 어휘발달(T3)에 미 치는 경로 모두 유의미한 영향을 미쳤다(부: $\beta=.113, p<.01$, 모: $\beta=.084, p<.01)$.

\section{통제변수 분석}

본 연구는 부모-자녀 언어 및 신체놀이 활동 참여와 자녀의 어 휘발달의 상호교류관계 있어 통제변수의 영향에 대해 살펴보 았다. 본 연구의 모형에 포함된 통제변수는 본 연구변인과 유 의미한 관계를 갖는 가구소득수준과 자녀의 인지능력을 각 시 점마다 통제하였다. 그 결과는 Table 7과 같다.

\section{Discussion}

본 연구는 영국 밀레니엄 코호트 연구(MCS)의 패널 데이터 중 유아기부터 아동 후기까지의 세 시점 자료를 사용하여 성 장기 자녀와 그 부모 간의 언어 및 신체놀이 활동 참여와 자녀 의 어휘발달 간의 안정성 및 상호교류적 관계를 자기회귀교차 지연모형을 통해 검증하였다. 본 연구 결과를 요약하고 논의 하면 다음과 같다.

첫째, 부모-자녀 언어/신체놀이 활동 참여와 자녀 어휘발달 은 모두 시간의 흐름에 따라 안정적이었다. 이전 시점의 부모자녀 언어 및 신체 놀이 활동 참여는 이후 시점에서의 부모-자 
녀 언어/신체놀이 활동에 유의미한 영향을 미치며, 이전 시점 의 자녀 어휘발달은 이후 시점에서의 자녀 어휘발달에 유의미 한 영향을 미치는 것으로 나타났다. 이는 세 변인이 각각 일시 적인 현상이 아니라 지속적으로 나타나는 현상이라는 것을 의 미한다. 이러한 결과에 대한 논의점을 살펴보면 다음과 같다. 먼저 부모-자녀 언어활동 참여의 안정성은 이전 시점에 부모 가 자녀에게 책을 많이 읽어주거나, 이야기를 많이 들려주고, 도서관을 데려가 주는 등 언어 활동 참여 빈도가 높을 경우 이 후 시점에도 언어 활동 공유를 많이 하는 경향이 있음을 의미 한다. 비록 부모-자녀 언어적 활동의 안정성을 직접적으로 살 펴본 선행연구들을 많이 발견하기 어려우나, 이러한 결과는 부모의 책읽기와 같은 문해 활동이 이후 도서관에 데려가기, 책 구입과 같은 간접적인 문해 활동으로 지속된다는 종단연구 결과(Sénéchal \& LeFevre, 2002)와도 유사하다.

또한 부모-자녀 신체놀이 활동 참여의 경우에도 이전 시점 의 부모-자녀 신체놀이 활동 참여는 이후 시점의 신체놀이 활 동에 안정적으로 영향을 미쳤다. 부모와 자녀가 함께 신체놀 이 활동을 꾸준히 참여할 경우 시간이 지나도 함께 신체놀이 활동을 즐겨 하거나, 신체놀이 활동을 지원하는 행동을 많이 하는 것으로 나타난 것이다. 이러한 결과는 부모-자녀 신체놀 이 활동의 빈도는 시간이 지나도 안정적이라는 Butte 등(2014) 의 연구결과와도 맥을 같이한다. 이처럼 부모-자녀 상호작용 활동 참여가 시간의 흐름에도 안정적인 결과로 나타난 것은 양육 초기에 이미 형성된 부모의 양육 관련 신념과 태도 그리 고 그로 인해 형성된 양육행동의 패턴은 자녀가 성장하여도 쉽게 바뀌지 않는 안정성을 가지고 있기 때문이라 유추할 수 있다(Landry, Smith, Swank, Assel, \& Vellet, 2001). 부모의 양육 관련 행동에 있어서 안정성은 부모의 특정 행동의 빈도와 전 체적 수준에 있어서 변화 또는 유사함이 오랜 시간 안정적인 것을 의미한다(Dallaire \& Weinraub, 2005).

마지막으로 자녀 어휘발달의 경우에도 이전 시점의 어휘 발달이 이후 시점의 어휘발달을 예측하였는데, 이는 아동의 어휘능력이 대체로 안정적이라는 선행 연구결과들(Bornstein, Hahn, \& Suwalsky, 2013; Felsenfeld, Broen, \& McGue, 1994)과 일치한다. 특히, Bornstein 등(2013)의 연구에 따르면 4세 때 어 휘능력이 높은 유아는 10 년 후 14 세가 될 때까지 어휘능력이 다른 아이들보다 더 높은 수준을 유지하는 것으로 나타났으 며, 이는 본 연구 결과처럼 유아기부터 아동후기까지 어휘능 력의 안정성을 지지하는 결과라 할 수 있다. 이러한 어휘발달 의 안정성은 언어를 습득하는데 있어 민감한 시기가 있음을 의미하는 것으로, 이런 언어발달의 민감한 시기에 대한 가설
을 처음 제기한 Lenneberg (1967)는 언어 형성과정에서 유아기 라는 특정 시기가 최종적인 어휘발달에 영향을 미칠 만큼 중 요한 시기임을 강조하였다. 다시 말해, 유아기부터 아동 후기 까지 자녀의 어휘발달이 안정적으로 유지되는 본 연구결과는 유아기에 언어 습득 능력이 높을 경우 이후 아동기 언어 수행 능력이 좋다는 언어발달에 있어서 민감한 시기가 있다는 가설 을 지지하고 있음을 알 수 있다.

둘째, 연구 변인들 간의 상호적 영향과 관련하여, 부모-자 녀 언어활동 참여와 자녀의 어휘발달 간 상호적 영향과 관련 하여 이전 시점의 부모-자녀 언어활동 참여가 이후 시점의 자 녀 어휘발달에 영향을 미치는 경로가 유의하였다. 즉, 본 연구 결과는 부모-자녀 언어활동 참여와 자녀의 어휘발달 간의 관 계에서 부모 효과를 지지하였다. 초기 부모와의 언어활동 상 호작용이 자녀의 표현언어능력에 긍정적 영향을 미친 본 연구 결과는 2 년 동안 자녀에게 책을 많이 읽어준(일주일에 5회 이 상) 그룹의 자녀들이 통제그룹 자녀들보다 개인적인 대화를 나눌 때 책에 나오는 특별한 어휘들과 복잡한 문장 형태를 많 이 표현한다고 보고한 선행연구들(Burgess, Hecht, \& Lonigan, 2002; Seo, 2013)과 비슷한 결과를 도출하였다. 또한 부모가 자 녀에게 다양한 이야기 거리를 들려주었을 때 1 년 후 자녀의 언어적 유창성에 긍정적 영향을 미치며(Park, Tsai, Liu, \& Lau, 2012), 부모가 도서관에 자주 데리고 가는 활동처럼 풍부한 문 해환경을 지원해주었을 때 이후 자녀의 말하기, 읽기 능력이 향상에 도움을 준다는(Gershoff, Aber, \& Clements, 2009) 연구 결과들과도 맥을 같이 한다.

이처럼 유아기 부모와 함께한 언어적 경험이 이후 어휘발달 에 효과가 있는 것으로 나타난 본 연구결과는 유아기 언어발달 을 위한 개입 프로그램 수행을 통해 그 효과성과 효율성을 다 룬 프로그램 연구의 결과와 일치하는 것으로, 영유아기 부모의 긍정적 상호작용 활동 참여와 같은 초기 개입은 이후 아동기, 청소년기를 비롯한 성인기 신체적 건강, 정서 발달, 인지능력 등 다양한 발달적 영역에 영향을 미친다. 무엇보다 유아기 가 정문해환경과 같은 부모의 언어활동 참여는 언어발달이 민감 한 시기에 자녀들이 많은 어휘를 청각적으로 경험하게 도와줌 으로써 보다 빨리 어휘를 습득하게 되고, 점차 뇌가 익숙한 단 어의 소리를 표현하게 되면서 언어 능력을 향상시킨다(Aamodt $\&$ Wang, 2012). 이는 언어발달이 이루어지는 민감한 시기가 있 으며, 부모는 이 시기에 적절한 경험을 제공해주어야 함을 의 미한다(Friederici \& Wartenburger, 2010). 반면, 언어발달에 민감 한 시기인 유아기에 좋은 언어 환경에서 자란 자녀들은 언어를 빠르게 흡수하게 되고 표현 어휘의 발달이 원활히 이루어져 장 
기적으로 아동기를 넘어 성인기까지 효과적인 언어발달을 이 루도록 해준다(Aamodt \& Wang, 2012). 다시 말해, 발달에 있어 민감한 시기라는 것은 적절한 발달을 위해서 일정한 경험이 필 요한 때를 의미하는 것으로(Schwartz, 2004), 유아기에 부모와 의 활발한 언어활동 경험은 향후 언어 발달을 위한 중요한 조 기 개입 전략이 될 수 있음을 예측해 볼 수 있다.

또한 부와 모의 부모-자녀 언어활동 각각이 자녀의 어휘발 달에 미치는 영향력을 살펴보았을 때, 부-자녀 간 언어활동 참 여보다 모-자녀 간 언어활동 참여가 자녀의 어휘발달에 조금 더 큰 영향력을 미치는 것으로 나타났다. 이와 관련하여 여러 선행연구들에서 어머니가 자녀에게 책을 읽어주는 빈도가 높 을 경우 그렇지 않은 어머니의 자녀보다 표현어휘능력과 의사 소통 기술을 더 향상시키는 것(Patterson, 2002)으로 나타났다 는 점에서 의미가 있다. 반면, 아버지의 언어활동은 어머니와 는 다른 형태의 경험을 제공한다는 Schwartz (2004)의 주장처 럼 부-자녀의 언어적 상호작용 활동은 어머니의 상호작용과 는 질적 측면에서 다소간 다르게 나타날 수 있다. 예로 아버지 는 자녀에게 책을 읽어줄 때 사실적이며 흥미위주의 상호작용 을 많이 하는 반면 어머니는 인지적 요구를 더 많이 하고, 언어 적인 규칙을 강조하면서 책을 읽어주며, 책을 읽는 동안 질문 하고 표현을 유도하며, 경험과 연결 짓거나 대화를 이끄는 모 습을 통해 자녀의 표현어휘발달을 촉진한다(Schwartz, 2004). 또한 책읽기 뿐 만 아니라 어머니는 자녀에게 다양한 이야기 를 들려줄 때 개방형 질문을 사용함으로써 자녀가 많은 어휘 를 표현할 수 있도록 하며(Sonnenschein \& Munsterman, 2002), 어머니가 자녀에게 들려주는 이야기의 정교성은 자녀 스스로 이야기를 꾸며내고 표현하는 능력을 장기적으로 향상시켜준 다(Low \& Durkin, 2001). 이를 통해 모-자녀 간 언어활동참여 가 자녀의 표현어휘발달에 미치는 관계에서 그 영향력이 높았 던 본 연구결과는 어머니의 언어활동의 참여가 자녀의 표현어 휘발달을 유도하는 중요한 예측 변인이라는 선행연구들을 뒷 받침하는 결과라 볼 수 있다.

더불어 본 연구결과에서는 유아기 부모-자녀 언어활동 참 여 빈도가 아동 후기 자녀의 어휘발달에 유의미한 영향을 미치 는 종단적 효과가 나타났다. 본 연구결과와 비슷한 맥락으로 Gottfried, Schlackman, Gottfried와 Boutin-Martinez (2015)는 부 모의 언어활동 제공과 자녀의 전반적 어휘발달을 살펴본 결과, 부모가 유아기 자녀와 책을 함께 읽는 빈도, 도서관과 같은 문 해 환경에 자주 방문하는 빈도 등이 이후 자녀의 아동기, 청소 년기의 전반적 언어능력과 학업 성취에 영향을 미치고 있음을 보고하였다. 이처럼 부모의 다양한 언어활동 참여가 자녀의 언
어발달에 장기적으로 영향을 미친 연구결과는 부모-자녀 활동 내에서의 상호작용 질도 중요하지만, 함께 보내는 시간도 자녀 발달에 종단적 효과가 있음을 뒷받침하는 결과라 할 수 있다.

또한 자녀의 어휘발달이 부모-자녀 언어활동 참여에 미친 영향 즉, '아동 효과'에서도 부모의 언어활동 참여 모두에서 유 의미한 영향을 미치는 것으로 나타났다. 이러한 아동 효과와 관련하여 지금까지 다수의 연구들은 부모의 양육 관련 행동 이 자녀의 특성에 영향을 미치는 단일 방향을 전제로 연구를 수행하고 있으며, 자녀의 특성이 부모의 양육 관련 행동에 미 치는 아동 효과는 이론적으로는 오랜 시간 강조되어 왔음에 도 불구하고 이를 분석한 경험적 연구는 상대적으로 부족하 다(Thornberry, Lizotte, Krohn, Farnworth, \& Jang, 1991). 이러 한 측면에서 자녀의 어휘발달이 부모-자녀 간 언어활동을 예 측한다는 본 연구 결과는 자녀의 언어능력이 부모의 인지적/ 언어적 자극을 일으키는 행동을 촉진한다는 종단 연구결과들( Bornstein et al., 2013; Tucker-Drob \& Harden, 2012)과 유사한 맥 락에서 이해될 수 있다. 즉, 자녀의 언어 발달 수준이 높을 경우 자신의 의사를 자유롭게 표현할 기회가 많아짐으로써, 부모의 언어활동을 유도 또는 촉진하고 강화하는 것으로 이해될 수 있다. 어휘능력 수준이 높은 자녀의 자극이 부모로 하여금 언 어적 활동, 특히 책읽기 또는 이야기 활동 등을 이끌어낸다는 점에서 자녀의 어휘발달과 부모의 언어자극은 서로 상승효과 를 일으키는 상호적 관계에 있음을 알 수 있다. 또한 이러한 경 로는 자녀의 표현어휘능력이 좋을수록 부모, 또래 등과의 관계 에서 친사회성, 사회적 기술이 증가하고, 이러한 자녀의 사회 적 기술은 부모로 하여금 긍정적 상호작용, 양육행동 등과 같 은 긍정적 피드백을 이끌어 낼 수 있음을 유추해볼 수 있다.

셋째, 부모-자녀 신체놀이 활동 참여와 자녀 어휘발달의 상 호적 영향 및 종단적 효과를 살펴보면, 부모-자녀 신체놀이 활동 참여가 자녀의 어휘발달에 미치는 영향은 어머니의 경 우 모-자녀 간 신체 놀이활동 참여(T1, T2)가 자녀의 어휘발 달(T2, T3)에 영향을 미쳤으며, 아버지의 경우 이전 시점에서 의 부-자녀 간 신체 놀이활동 참여(T2)가 이후의 자녀 어휘발 달(T3)에 유의미한 영향을 미치는 것으로 확인되었다. 이처 럼 부모-자녀 신체놀이 활동 참여가 자녀의 어휘발달에 긍정 적 영향을 미치는 것으로 나타난 결과는 부모-자녀 신체놀이 활동 참여 빈도가 높을수록 자녀의 언어 능력이 높음을 의미 한다. 이는 부모와 함께 신체놀이를 할수록 자녀의 경우 인지/ 언어능력에 있어서 장기적으로 향상된다는 연구 결과(TamisLemonda, Shannon, Cabrera, \& Lamb, 2004)를 지지하며, 부모자녀 신체놀이 활동 빈도가 높을수록 자녀의 문해 능력과 학 
업 성취 능력이 우수하다는(Becker et al., 2013) 연구 결과와도 맥을 같이한다. 이러한 결과와 관련해 신체놀이 활동 경험이 자녀의 언어/인지발달에 긍정적 영향을 미치는 과정을 뇌과 학적 관점에서 접근해보면 신체놀이 활동을 통해 몸을 움직 일 경우 언어를 담당하는 측두엽/브로카영역과 밀접한 관련 이 있는 전전두엽이 발달하기(Aamodt \& Wang, 2012)때문으 로 이해할 수 있다. 또한 신체놀이 활동을 많이 한 아동의 경우 해마와 인지적 유연성을 담당하는 배측선조체(dorsal striatum) 가 또래 아동보다 더 크다고 보고되고 있다(Aamodt $\&$ Wang, 2012). 이처럼 신체놀이 활동을 통해 언어기능을 담당하고 있 는 뇌 영역들이 활발해 진다는 것은 부모-자녀의 신체놀이 활 동 참여 빈도가 자녀의 언어능력에 긍정적 영향을 미치는 것 으로 나타난 본 연구의 결과를 뒷받침 해주는 관점이다.

또한 부모-자녀 신체놀이 활동 참여가 자녀의 어휘발달에 유의미한 영향을 미친 본 연구결과는 부모-자녀가 신체놀이 활동을 함께하면서 주고받을 수 있는 언어적 환경으로 설명할 수 있다. 즉, 부모는 자녀와 신체놀이 활동을 하는 동안 움직 임과 관련된 상태/동작 동사들을 표현함으로써 자녀들이 자 연스럽게 다양한 어휘들을 습득할 수 있게 도와주며, 신체놀 이 활동에 관한 규칙을 지시 또는 설명해줌으로써 자녀는 부 모가 표현하는 언어의 의미를 파악할 수 있는 기술을 획득하 게 된다. 더욱이 부모는 자녀들의 움직임이 나타날 때마다 끊 임없이 주석을 달며, 언어적으로 묘사하고 이름을 붙여줌으로 써(Hillman, Castelli, \& Buck, 2005), 자녀의 언어적 환경을 풍 부하게 만든다. 특히, 부모가 신체놀이 활동을 하면서 동시에 표현하는 말과 신체적 움직임은 자녀에게 언어/비언어적으 로 각인되면서 자녀의 언어 능력을 증진시킨다(Tomporowski, Davis, Lambourne, Gregoski, \& Tkacz, 2008). 따라서 부모의 신 체놀이 활동 경험이 자녀의 어휘발달에 유의한 영향을 미친 본 연구결과는 부모-자녀 신체놀이 활동을 통해 발현되는 인 지적/언어적 자극이 자녀의 언어 능력을 한 층 더 발달시키는 역할을 하고 있음을 보여준다고 할 수 있다. 또한 이러한 결과 는 혼자 신체놀이 활동을 했을 때 발현되는 아동의 발달적 측 면보다, 신체놀이 활동 시 타인과의 상호 언어적 교류를 통해 나타나는 아동의 발달적 효과를 강조할 수 있다는 점에서 중 요한 의의를 갖는다.

더불어 유아기의 부모-자녀 신체 놀이활동 참여가 아동 후 기 자녀 어휘발달에 영향을 미친 종단적 결과는 유아기 부모와 의 긍정적 상호작용 경험이 촉매제 역할을 함으로써 아동 후기 언어발달까지 지속적으로 영향을 미쳤을 것으로 추측된다. 많 은 연구들에서 어린 연령부터 신체놀이 활동을 경험한 유아들
은 이후 아동기, 청소년기 그리고 성인기까지 언어능력을 포함 한 인지기능이 높은 것으로 보고하고 있으며, 이를 유아기 신 체놀이 활동 경험에 대한 만성효과라 강조한다(Fedewa \& Ahn, 2011; Tomporowski et al., 2008). 요약하면 언어발달의 민감한 시기인 유아기에 부모-자녀 신체놀이 활동 경험은 어휘발달의 안정성을 유지하는 촉매제 역할을 하고 있음을 알 수 있다.

다음으로 자녀의 어휘발달이 부모-자녀 신체놀이 활동 정 도에 미치는 아동 효과를 살펴보면, 아버지의 경우 이전 시점 의 자녀 어휘발달(T1)이 이후 시점의 부-자녀 간 신체놀이 활 동 참여(T2)를 예측하였다. 이는 Pentz와 Riggs (2013)가 보고 한 자녀가 언어/인지발달이 더 높을수록 아버지와 신체놀이 활동을 하는 빈도가 높다는 연구결과와 맥을 같이 한다. 반면 어머니의 경우 이전 시점의 자녀 어휘발달(T1)이 이후 시점의 모-자녀 신체놀이 활동 참여(T2)에 영향을 주지 않았다. 이러 한 결과는 아버지의 신체놀이 활동 개입 여부는 어머니보다 자녀의 특성으로부터 더 영향을 받는다는 것으로 자녀의 어휘 발달 수준이 높을수록 아버지는 자녀와 신체적 상호작용 또한 더 많이 하는 것을 의미한다. 이는 아버지의 상호작용 참여는 자녀의 언어 능력에 따라 달라짐을 보고한 Holmes와 Huston (2010)의 연구결과와 맥을 같이 한다. Holmes와 Huston (2010) 의 연구결과에 따르면 자녀의 어휘 능력, 문법, 단어추론 능력 이 좋고, 사회적 기술 능력이 뛰어날 경우 아버지의 양육 참여 비율이 높고, 자녀와 긍정적 놀이 상호작용을 할 기회가 많다 고 보고하였다. 이러한 결과는 직접 상호작용을 해야 하는 언 어적 상호작용 속에서 자녀가 언어적으로 지연 또는 결함을 보일 경우 아버지 또한 자녀의 의도를 파악하는데 어려움이 있어 자녀에게 적절한 자극을 제공하지 못할 수 있다고 해석 해 볼 수 있다. 즉, 아버지의 경우 어머니처럼 주도적으로 언어 적 교류를 하기보다, 다소 반응적인 경향성을 보여 자녀의 언 어 발달 수준에 따라 아버지의 행동과 반응 수준이 달라질 수 있음을 유추해 볼 수 있다.

이상으로 부모-자녀 언어/신체놀이 활동 참여와 자녀의 어 휘발달의 상호교류관계에 관한 본 연구 결과를 종합하여 논 의해보면 다음과 같다. 우선 본 연구는 부모-자녀 언어활동 뿐 만 아니라 신체놀이 활동을 함께 살펴보았고, 각각의 활동 경 험이 자녀의 어휘발달에 유의미한 결과를 제공하였다. 이는 지금까지 부모-자녀 활동을 언어 또는 신체놀이 활동만 단편 적으로 살펴보았던 연구들과 달리 언어와 신체놀이 활동을 모 두 살펴봄으로써 각 활동 참여가 자녀의 발달에 어떠한 영향 을 미치는지 함께 살펴볼 수 있었다는데 큰 의의가 있다. 또한 최근 자녀의 발달적 요인이 부모의 상호작용 활동 참여에 영 
향을 준다는 아동효과가 강조되면서 이 둘의 상호인과적 관계 를 살펴봐야 한다는 주장이 제기되고 있다. 이에 본 연구는 부 모-자녀 언어/신체 활동 참여와 자녀의 어휘능력이 시간의 흐 름에 따라 상호 어떠한 영향을 미치는가에 대해 종단 자료를 기반으로 실증해보았으며 이를 통해 부와 모 각각의 상호작 용 활동 참여가 자녀 어휘발달과의 상호교류관계에서 다소 차 이가 있는 것으로 나타남으로써 향후 부 또는 모-자녀 관련 정 책, 부모교육 프로그램에서 이러한 요인과 발달성과를 제고시 킬 수 있는 방안들에 대해 모색하였다는데 의의가 있다.

연구의 제한점과 함께 후속 연구를 위한 제언을 하면 다음 과 같다. 첫째, 본 연구는 영국의 패널데이터를 통해 지정된 척 도와 질문지를 사용하였다. 실제로 본 연구에 사용된 변인들 중 부모-자녀 언어활동을 묻는 질문의 경우 책읽기, 도서관 데려가 기, 이야기 들려주기로 구성되었으며, 신체놀이 활동의 경우 실 내/외의 놀이활동 참여를 묻는 문항으로 구성되었다. 또한 부 모-자녀 언어/신체놀이 활동 질문은 '얼마나 함께 활동을 하였 는가' 빈도를 조사하여 산출하였다. 즉, 본 연구는 부모-자녀 언 어 및 신체놀이 활동 참여 정도와 자녀의 어휘발달에 미치는 종 단적 영향력을 살펴보는데 주안점을 두고, 부모-자녀 활동 참 여 빈도에 초점을 두고 탐색하였다, 후속 연구에서는 언어활동 과 신체놀이 활동 영역에서 구체적으로 어떤 유형의 활동이 자 녀의 어휘발달에 유의한 영향을 미치는지 탐색하기 위해 좀 더 확장된 질문을 활용한다면 흥미로울 것으로 사료된다.

둘째, 본 연구가 한국과 상이한 문화적 맥락을 가진 영국의 자료를 토대로 이루어진 점을 고려해 볼 때, 연구결과에서 입 증된 부모-자녀 언어/신체 활동 특성과 자녀의 어휘발달 간의 관련성이 한국 사회에서는 다른 양상으로 나타날 수 있을 것 으로 본다. 현대사회로 들어와 한국 사회 또한 영국 사회와 비 슷하게 개인주의 문화, 독립성, 개방성이 강조되고 있으며, 유 튜브와 같은 매체를 통해 서구 문화를 자연스럽게 받아들이고 있다. 그럼에도 불구하고 한국보다 개방적이고 비통제적인 양 육태도를 가진 영국 사회와 유교문화를 기반으로 보수적이며 통제적인 양육 유형을 보이는 한국사회는 자녀와의 언어/신 체 활동에서 영국과 차이를 보일 수 있다. 예로, 부모-자녀 신 체놀이 활동에 있어 영국은 바깥 놀이 활동이 주로 이루어지 는 반면, 한국의 경우 실내에서 할 수 있는 활동이 주로 이루어 지는 차이가 있다(Choi, 2003). 이러한 미시적 부분에서의 문 화적 차이의 가능성이 존재하지만, 부모-자녀의 언어/신체 활 동 참여와 자녀 어휘발달 사이의 유의한 관련성을 입증한 본 연구의 전반적 결과는 한국 상황에도 중요한 시사점을 가질 것이다. 즉, 한국 사회에서도 부모의 양육 관련 상호작용 활동
이 서구 문화와 비슷해지고 있는 추세임을 고려해볼 때, 본 연 구 결과는 부모-자녀 언어/신체 활동의 활성화를 위한 기초자 료가 될 것으로 사료된다.

\section{Acknowledgements}

This work was supported by the Millennium Cohort study of the UK Data Service (ukd1217064383).

\section{Notes}

This article is a part of the first author's doctoral dissertation submitted in 2019, and was presented at the 2020 Annual Spring On-ling Conference of the Korean Association of Child Studies.

\section{Conflict of Interest}

No potential conflict of interest relevant to this article was reported.

\section{References}

\section{In English}

Aamodt, S., \& Wang, S. (2012). Welcome to your child's brain: How the mind grows from birth to university (Reprint Ed.). London: Bloomsbury USA.

Bartle-Haring, S., \& Sabatelli, R. (1998). An intergenerational examination of patters of individual and family adjustment. Journal of Marriage and Family, 60(4), 903-911. doi:10. $2307 / 353633$

Becker, S., Peter, M., Fritsch, D., Philipp, D., Baier, P., \& Dibak, C. (2013). Combined grammar for the modeling of building interiors. ISPRS Annals of Photogrammetry, Remote Sensing and Spatial Information Sciences, II-4/W1, 1-6. doi:10.5194/isprsannals-II-4-W1-1-2013

Bornstein, M. H., Hahn, C.-S., \& Suwalsky, J. T. D. (2013). Language and internalizing and externalizing behavioral adjustment: Developmental pathways from childhood to adolescence. Development and Psychopathology, 25(3), 857 878. doi:10.1017/S0954579413000217

Burgess, S. R., Hecht, S. A., \& Lonigan, C. J. (2002). Relations of 
the home literacy environment (HLE) to the development of reading-related abilities: A one-year longitudinal study. Reading Research Quarterly, 37(4), 408-426.

Butte, N. F., Gregorich, S. E., Tschann, J. M., Penilla, C., Pasch, L. A., De Groat, C. L.,...Martinez, S. M. (2014). Longitudinal effects of parental, child and neighborhood factors on moderate-vigorous physical activity and sedentary time in Latino children. International Journal Behavioral Nutrition and Physical Activity, 11(108), 1-12. doi:10.1186/s12966014-0108-x

Choi, Y., Kim, Y. S., Kim, S. Y., \& Park, I. J. K. (2013). Is Asian American parenting controlling and harsh? Empirical testing of relationships between Korean American and Western parenting measures. Asian American Journal of Psychology, 4(1), 19-29. doi:10.1037/a0031220

Dallaire, D. H., \& Weinraub, M. (2005). The stability of parenting behaviors over the first 6 years of life. Early Childhood Research Quarterly, 20(2), 201-219. doi:10.1016/j.ecresq.2005.04.008

Fedewa, A. L., \& Ahn, S. (2011). The effects of physical activity and physical fitness on children's achievement and cognitive outcomes: A meta-analysis. Research Quarterly for Exercise and Sport, 82(3), 521-535. doi:10.1080/02701367.2011.1 0599785

Fein, G. G. (1918). Pretend play in childhood: An integrative review. Child Development, 52(4), 1095-1118. doi:10.2307/1129497

Felsenfeld, S., Broen, P. A., \& McGue, M. (1994). 28-year followup of adults with a history of moderate phonological disorder: Educational and occupational results. Journal of Speech, Hear, and Research, 37(6), 1341-1353. doi:10.1044/ jshr.3706.1341

Fitzgerald, C. E., Hadley, P. A., \& Rispoli, M. (2013). Are some parents' interaction styles associated with richer grammatical input? American Journal of Speech-Language Pathology, 22(3), 476-488. doi:10.1044/1058-0360(2012/11-0111)

Friederici, A. D., \& Wartenburger, I. (2010). Language and Brain. Wiley Interdisciplinary Reviews: Cognitive Science, 1(2), 150159. doi:10.1002/wcs.9

Gershoff, E. T., Aber, J. L., \& Clements, M. (2009). Parent learning support and child reading ability: A crosslagged panel analysis for developmental transactions. In A. Sameroff (Ed.), The transactional model of development: How children and contexts shape each other (pp. 203-220). Washington, DC: American Psychological Association.

Girolametto, L., Wiigs, M., Smyth, R., Weitzman, E., \& Pearce, P. S. (2001). Children with a history of expressive vocabulary delay: Outcomes at 5 years of age. American Journal of Speech-Language Pathology, 10(4), 358-369. doi:10.1044/1058-0360(2001/030)

Glazer, S. M., \& Burke, E. M. (1994). An integrated approach to early literacy: Literature to language. London: Pearson.
Gottfried, A. W., Schlackman, J., Gottfried, A. E., \& BoutinMartinez, A. S. (2015). Parental provision of early literacy environment as related to reading and educational outcomes across the academic lifespan. Parenting: Science and Practice, 15(1), 24-38. doi:10.1080/15295192.2015.9 92736

Hickman, J. (1981). A new perspective on response to literature: Research in an elementary school setting. Research in the Teaching of English, 15(4), 343-354.

Hillman, C. H., Castelli, D. M., \& Buck, S. M. (2005). Aerobic fitness and neurocognitive function in healthy preadolescent children. Medicine and Science in Sports and Exercise, 37(11), 1967-1974. doi:10.1249/01. mss.0000176680.79702.ce

Hoff-Ginsberg, E. (1991). Mother-child conversation in different social classes and communicative settings. Child Development, 62(4), 782-796. doi:10.1111/j.14678624.1991.tb01569.x

Holmes, E. K., \& Huston, A. C. (2010). Understanding positive father-child interaction: Children's, fathers', and mothers' contributions. Fathering: A Journal of Theory, Research, and Practice about Men as Fathers, 8(2), 203-225.

Kermani, H., \& Brenner, M. E. (2000). Maternal scaffolding in the child's zone fo proximal development across tasks: Crosscultural perspectives. Journal of Research in Childhood Education, 15(1), 30-52. doi:10.1080/02568540009594774

Landry, S. H., Smith, K. E., Swank, P. R., Assel, M. A., \& Vellet, S. (2001). Does early responsive parenting have a special importance for children's development or is consistency across early childhood necessary? Development Psychology, 37(3), 387-403. doi:10.1037/0012-1649.37.3.387

Lenneberg, E. H. (1967). The biological foundations of language. Hospital Practice, 12(2), 59-67. doi:10.1080/21548331.19 67.11707799

Levy, A. K. (1984). The language of play: The role of play in language development. Early Child Development and Care, 17(1), 49-61. doi:10.1080/0300443840170106

Lewis, K., Sandilos, L. E., Hammer, C. S., Sawyer, B. E., \& Méndez, L. I. (2016). Relations among the home language and literacy environment and children's language abilities: A study of head start dual language learners and their mothers. Early Education and Development, 27(4), 478-494. doi:10.1080/10409289.2016.1082820

Low, J., \& Durkin, K. (2001). Individual differences and consistency in maternal talk style during joint story encoding and retrospection: Associations with children's longterm recall. International Journal of Behavioral Development, 25(1), 27-36. doi:10.1080/01650250042000122

Park, H., Tsai, K. M., Liu, L. L., \& Lau, A. S. (2012). Transactional associations between supportive family climate and young 
children's heritage language proficiency in immigrant families. International Journal of Behavioral Development, 36(3), 226-236. doi:10.1177/0165025412439842

Patterson, J. L. (2002). Relationship of expressive vocabulary to frequency of reading and television experience among bilingual toddlers. Applied Psycholinguistics, 23(4), 493-508. doi:10.1017/S0142716402004010

Pence, K. L., Justice, L. M., \& Wiggins, A. K. (2008). Preschool teachers' fidelity in implementing a comprehensive languagerich curriculum. Language, Speech, and Hearing Services in Schools, 39(3), 329-341. doi:10.1044/0161-1461(2008/031)

Pentz, M. A., \& Riggs, N. R. (2013). Longitudinal relationships of executive cognitive function and parent influence to child substance use and physical activity. Prevention Science, 14, 229-237. doi:10.1007/s11121-012-0312-3

Piaget, J. (1954). The construction of reality in the child (M. Cook, Trans.). New York: Basic Books.

Roberts, G., Good, R., \& Corcoran, S. (2005). Story retell: A fluency-based indicator of reading comprehension. School Psychology Quarterly, 20(3), 304-317. doi: 10.1521/ scpq.2005.20.3.304

Rogoff, B., Ellis, S., \& Gardner, W. (1984). Adjustment of adult-child instruction according to child age and task. Developmental Psychology, 20(2), 193-199. doi:10.1037/0012-1649.20.2.193

Sameroff, A. (2009). The transaction model. In A. Sameroff (Ed.), The transactional model of development: How children and contexts shape each other (pp. 3-21). Washington, DC: American Psychological Association.

Schmidt, L., \& Sevak, P. (2006). Gender, marriage, and asset accumulation in the United States. Feminist Economics, 12(1-2), 139-166. doi:10.1080/13545700500508445

Schwartz, J. (2004). Air pollution and children's health. Pediatrics, 113(4), 1037-1043.

Sénéchal, M., \& LeFevre, J.-A. (2002). Parental involvement in the development of children's reading skill: A five-year longitudinal study. Child Development, 73(2), 445-460.

Sénéchal, M., Pagan, S., Lever, R., \& Ouellette, G. P. (2008). Relations among the frequency of shared reading and 4-year-old children's vocabulary, morphological and syntax comprehension, and narrative skills. Early Education and Development, 19(1), 27-44. doi:10.1080/10409280701838710

Smith, P. K., \& Cowie, H. (1991). Understanding children's development (2nd ed.). Hoboken, NJ: Blackwell Publishers.

Solter, A. J. (2013). Attachment play: How to solve children's behavior problems with play, laughter, and connection (Illustrated ed.). Goleta, CA: Shining Star Press.

Sonnenschein, S., \& Munsterman, K. (2002). The influence of home-based reading interactions on 5-year-olds' reading motivations and early literacy development. Early Childhood Research Quarterly, 17(3), 318-337. doi:10.1016/S0885-
2006(02)00167-9

Sy, S. R., Gottfried, A. W., \& Gottfried, A. E. (2013). A transactional model of parental involvement and children's achievement from early childhood through adolescence. Parenting: Science \& Practice, 13(2), 133-152. doi:10.1080/ 15295192.2012.709155

Tamis-LeMonda, C. S., Shannon, J. D., Cabrera, N. J., \& Lamb, M. E. (2004). Fathers and mothers at play with their 2and 3-year-olds: Contributions to language and cognitive development. Child Development, 75(6), 1806-1820. doi:10.1111/j.1467-8624.2004.00818.x

Thornberry, T. P., Lizotte, A. J., Krohn, M. D., Farnworth, M., \& Jang, S. J. (1991). Testing interactional theory: An examination of reciprocal causal relationships among family, school, and delinquency. The Journal of Criminal Law and Criminology, 82(1), 3-35. doi:10.2307/1143788

Tomlinson, B., \& Masuhara, H. (2009). Playing to learn: A review of physical games in second language acquisition. Simulation \& Gaming, 40(5), 645-668. doi:10.1177/1046878109339969

Tomporowski, P. D., Davis, C. L., Lambourne, K., Gregoski, M., \& Tkacz, J. (2008). Task switching in overweight children: Effects of acute exercise and age. Journal of Sport \& Exercise Psychology, 30(5), 497-511. doi:10.1123/jsep.30.5.497

Tucker-Drop, E. M., \& Harden, K. P. (2012). Early childhood cognitive development and parental cognitive stimulation: Evidence for reciprocal gene-environment. Development Science, 15(2), 250259. doi:10.1111/j.1467-7687.2011.01121.x

Umek, L. M., Podlesek, A., \& Fekonja, U. (2005). Assessing the home literacy environment. European Journal of Psychological Assessment, 21, 271-281. doi:10.1027/10155759.21.4.271

Vygotskiľ, L. S., Hanfmann, E., \& Vakar, G. (1962). Thought and Language. Cambridge, MA: MIT Press.

Zareva, A., Schwanenflugel, P., \& Nikolova, Y. (2005). Relationship between lexical competence and language proficiency: Variable sensitivity. Studies in Second Language Acquisition, 27(4), 567-595. doi:10.1017/S0272263105050254

\section{In Korean}

Choi, K.-R. (2003). The influence of family leisure activities on emotional dynamics. The Korean Journal of Physical Education, 42(3), 175-184.

Han, J. H., \& Hong, G. O. (2000). Maternal self-perception profile and parenting behaviors-Mothers for kindergarten children-. Journal of Future Early Childhood Education, $7(1), 85-111$.

Jang, H., \& Lim, J. Y. (2013). The effects of adolescent's stress, the frequency of conversation with parents, ways of stress coping and anger expression on life satisfaction. Journal of 
Parent Education, 5(1), 17-35.

Kim, H.-S. (2010). The effects of mothers' parenting behavior frequency and parental demand for mature behavior on their preschoolers' prosocial behaviors. Korea Journal of Child Care and Education, (64), 155-177.

Kim, S., \& Kwak, K. (2015). Exploring the effects on intelligence development at seven years of age: On the home environments and child development at three years. The Korean Journal of Human Development, 22(2), 75-91. doi:10.15284/kjhd.2015.22.2.75

Kwak, K., Yoo, J.-M., \& Kim, J.-M. (2007). The relation of poverty, parent's variances, home environment and child development in the 3-year-old children. The Korean Journal of Developmental Psychology, 20(1), 1-19.

Lee, J.-S., \& Han, J. (2004). The effects of mothers' parental efficacy and parental practices on children's social ability. Journal of Korean Home Management Association, 22(6), 6373.

Lee, J.-Y., \& Kim, Y.-T. (2009). A comparative study of group and individual test results on vocabulary test administered to teenagers. Journal of Speech-Speech \& Hearing Disorders, 18(1), 129-143. doi:10.15724/jslhd.2009.18.1.009

Lee, K. S., Kim, S.-H., \& Kim, M.-J. (2011). The impact of children's basic language abilites at age 5 , on their vocabulary and language abilites in first grade. Journal of Early Childhood Education, 31(5), 299-322.
Rhee, U. H., Lee, J. R., Kim, M. S., \& Jun, H. J. (2010). A longitudinal study on early school adjustment and the academic performance of children in low-income familes. Korean Journal of Child Studies, 31(1), 65-82.

Seo, H. (2013). The parental education program guidelines for the improvement of the adolescent verbal culture. Journal of Speech Communication, 22, 355-382. doi;10.18625/ jsc.2013..22.355

Yang, M. J., \& Bang, H. J. (2014). The relation among shyness, cognitive ability, maternal parenting behaviors, withdrawal and anxiety, depression: moderation effect of maternal parenting behaviors. Journal of Emotional \& Behavioral Disorders, 30(4), 363-386.

\section{ORCID}

Ji-Yeong Joo

Sae-Young Han https://orcid.org/0000-0003-4950-4659

https://orcid.org/0000-0001-8207-5927
Received October 31, 2020

Revision received December 2, 2020

Accepted December 8, 2020 